\title{
Gc-Ms Analysis of Ethanolic Stem Extract of Clausena anisata (Willd.) Hook F Ex Benth
}

\author{
Arsia Tarnam Yakoob', Nargis Begum Tajuddin', Shilu Mathew', Muhammad Ilyas Mohammed Hussain', \\ Ishtiaq Qadri*
}

\section{Arsia Tarnam Yakoob', Nargis Begum Tajuddin', Shilu Mathew', Muhammad llyas Mohammed Hussain', Ishtiaq Qadri ${ }^{2 *}$}

'Department of Biotechnology, Jamal Mohamed College (Autonomous), Trichy, INDIA.

${ }^{2}$ Division of Virology, Department of Biological Sciences, Faculty of Science, King Abdulaziz University, JEDDAH, KSA

Correspondence

Prof.Ishtiaq Qadri

Division of Virology, Department of Biological Sciences, Faculty of Science, King Abdulaziz University, Jeddah Jeddah,K.S.A

Mobile 00966500665783

Email: ishtiaqmq@gmail.com

DOI : 10.5530/pj.2016.6.9

Article Available online http://www.phcogj.com/v8/i6

\section{Copyright}

(C) 2016 Phcog.Net. This is an openaccess article distributed under the terms of the Creative Commons Attribution 4.0 International license.

\begin{abstract}
Objective: In the present study, the bioactive components present in the ethanol stem extract of Clausena anisata was analyzed by using Gas Chromatography Mass Spectrometry analysis technique (GC-MS). Clausena anisata, a medicinal plant belonging to the family Rutaceae, is represented by 20 species available in India and used traditionally for the treatment of several ailments but there is a requirement to identify its phytoconstituents, its target, mode of action and treatment using plant products either alone or in combination with synthetic drugs. Methods: Clausena anisata stem was procured from Manamettupatti, a village of Pudukottai District, Tamil Nadu. The shade dried stem was powdered and extracted using ethanol by maceration method. One microlitre of the extract was subjected to GC-MS analysis to detect the presence of bioactive compounds present in the stem of $C$. anisata. Results:The results showed that the ethanol stem extract of $C$. anisata contained nine bioactive compounds, of which the major one is n-hexadecanoic acid (78.54\%), followed by 8-octadecenoic acid, methyl ester, [E]- $(6.638 \%)$. The total number of compounds obtained was compared with National Institutes of Standard and Technology (NIST) library that contains more than 62,000 known compounds based on retention time and molecular mass. Conclusion: In this study, nearly nine compounds have been identified from the ethanolic stem extract of C. anisata using GC-MS analysis which was mainly composed of fatty acids and sterols. The GC-MS analysis is used to understand the nature of active principles present in this plant revealed that the plant can be used as a potential source of new useful drugs.

Key words: C. anisata, GC-MS analysis, Ethanol, maceration and phytoconstituents.
\end{abstract}

\section{INTRODUCTION}

Clausenaanisataof family Rutaceae is locally known as "Kattukarveppillai", is a deciduous shrubs or small treethat grows up to $10 \mathrm{~m}$, found in India, Tropical and South East Asia,which is indigenous in South Africa. Leaves are pinnately compound with 10 to 17 alternate leaflets and a terminal leaflet. The leaves are densely dotted with pellucid glands and have a strong scent when bruised. Flowers are small and attractive, white with orange-yellow stamens and havinggynophores. In Mozambique, it is locally known as "Horse wood". ${ }^{1}$ In Clausena anisata is the iron content was found to be $>1000 \mu \mathrm{g} /$ day and this may be useful for the persons with micronutrient deficiency. ${ }^{2}$ The dry mass per unit area of C. anisatais 3.24, nitrogen concentration per unit dry mass is 22.3 and water concentration per unit dry mass is $2.5 .^{3}$ They have the ability to withstand heavy pruning, easy to grow and free of pests and diseases. Nearly about 9 out of 23 known species of Clausena genus were explored and identified for chemical and biological studies.
Traditional medicine practitioners in Africa use the dried leaves of C. anisata like filling material for mattresses and pillows against lice, fleas and bedbugs. Roots are chewed to combat indigestion. ${ }^{4}$ As snake-bite antidote, to cleanse the uterus, in skin diseases ${ }^{5}$ and increase milk production after child birth, ${ }^{6}$ gonorrhea and haemorrhoids, as pesticides, ${ }^{5}$ anti feedant in worms, anti-inflammatory, antifungal and antiviral, ${ }^{7,8}$ antibacterial activity, diabetes, ${ }^{9}$ rheumatism, migraine headache, management of epilepsy, cough and treatment of tuberculosis, ${ }^{10}$ mosquito repellant against Anopheles arabiensis, syphilis, kidney ailments and against HIV. ${ }^{11}$ A decoction prepared from boiled stem bark extract of C. anisata was taken internally for two weeks by akwaibom state people to treat measles. Several studies have been conducted to comprehend these effects. Based on the above findings, in the present study the ethanolic stem extract of C. anisata was analyzed for the presence of bioactive components by using GC-MS analysis. 


\section{MATERIALS AND METHODS}

Plant collection: The fresh stems of C. anisata were procured during the months of October to November,2013 from Manamettupatti, Viralimalai Taluk (Pudukottai District, Tamilnadu). The botanical identity of the plant specimen was identified by Dr. S. John Britto, Director, The Rapinat Herbarium and Centre for Molecular Systematics, St. Joseph's College (Campus) Tiruchirappalli- 620002 and autheniticated as Clausena anisata (Willd.) Hook f. ex. Benth. The stem parts were washed with tap water followed by distilled water and shade dried in a well ventilated room. The dried stem materials were powdered, stored in an air tight container and used for further solvent extraction.

Preparation of the ethanol extract: The powdered stem was extracted using ethanol in the ratio of 1:10 by maceration method. After $48 \mathrm{hrs,}$ the extracts were filtered through Whatmans No: 1filter paper. The stem material was then macerated again with ethanol and the combined filtrate obtained from the first and the second maceration was then concentrated to dryness under controlled temperature $40-50^{\circ} \mathrm{C}$ using Rota evaporator (Yamato, Japan (Model-RE801)). The extract was preserved for further use.

GC-MS analysis: GC-MS analysis was carried out on a JEOL GCMATE II and gas chromatograph interfaced to a mass spectrometer (GC - MS) instrument. High resolution mass spectra were acquired at a resolving power of 5000 (20\% height definition) and scanning the magnet from $\mathrm{m} / \mathrm{z} 65$ to $\mathrm{m} / \mathrm{z} 350$ at 1 second per scan. The column (HP5) was fused silica $50 \mathrm{~m} \times 0.25 \mathrm{~mm}$. Analysis conditions were $20 \mathrm{~min}$ at $100^{\circ} \mathrm{C}$, $3 \mathrm{~min}$ at $235^{\circ} \mathrm{C}$ for column temperature, $240^{\circ} \mathrm{C}$ for injector temperature, helium was the carrier gas and split ratio was 5:4. The sample $(1 \mu \mathrm{l})$ was evaporated in a split less injector at $300^{\circ} \mathrm{C}$. Run time was $30 \mathrm{~min}$.

Identification of compounds: The compounds were identified by gas chromatography coupled with mass spectrometry. Interpretation on mass spectrum GC-MS was conducted using the database of National Institute Standard and Technology (NIST) having more than 62,000 patterns. The spectrum of the unknown component was compared with the spectrum of the known components stored in the NIST library. The name, molecular weight and structure of the components were ascertained.

\section{RESULTS}

Preliminary GC-MS analysis was carried out for crude ethanol stem (Figure 1) of C. anisata to determine the phytoconstituents. The chromatogram revealed that the ethanol stem extract is rich in fatty acids and sterols and the presence of nine components in the ethanol stem extract (Table 1). The major components are n-hexadecanoic acid (78.54\%), followed by 8 -octadecenoic acid, methyl ester, [E] - (6.638\%) and other seven minor components such as Heptadecanoic acid, 9-methyl-, methyl ester (2.985\%), Octadec -9-enoic acid (2.67\%), Isoxazole, 5-(3,3-dicyano1-cyclohexylidene-2-morpholino-prop-2-enyl)-3-p-methoxy phenyl(2.340\%),(3,4-dimethyl-5-oxo-2,5-dihydr0-1H-pyrrol-2yl)-(4,4dimethyl-5-(2,3,3-trimethyl-5-methylthio-3,4-dihydro-2H-pyrrol-2-yl methylene) pyrrolidin-2-ylene)-thioacetic acid, 3-(tert, -butyl) ester (2.134\%), Pentadecanoic acid, 13-methyl ester-, methyl ester (1.876\%) and Dipyrimadole $(0.686 \%)$.

\section{DISCUSSION}

The phytoconstituents are important compounds that are responsible for the medicinal properties and act as a potential source for neutraceuticals. In the present study, GC-MS analysis of ethanol stem extract of $C$. anisata showed the presence of nine compounds. The compounds were identified based on the retention time and molecular formula. Among the identified phytochemicals, n-hexadecanoic acid(78.54\%) and 8-octadecenoic acid, methyl ester, [E]-(6.638\%) was found to be predominant in the extract and was corroborated with ${ }^{12}$ in the ethanolic leaf extracts of Indigofera suffruticosa. This compound was reported to have hypercholesterolemic, anti-inflammatory, antioxidant ${ }^{13}$ and antimicrobial activity. ${ }^{14}$ Pentadecanoic acid, 13-methyl ester-, methyl ester(1.876\%) was reported to possess antioxidant activity, ${ }^{14}$ Octadec -9-enoic acid $(2.67 \%)$ activity was found to have cancer preventive and insectifuge. Dipyrimadole $(0.686 \%)$ is reported to prevent blot clots, to dilate blood vessels, ${ }^{15}$ it inhibits the replication of mengovirus RNA. ${ }^{16}$ The bioactive compounds isolated from crude culture extracts produced by C. albicans isolated from the coastal mangrove ecosystem ${ }^{17}$ also reported the presence of is oxazole, 5-(3,3-dicyano-1-cyclohexylidene-2-morpholino-prop-2-enyl)-3-p-methoxy phenyl-, that was in accordance with this study. Thus this type of GC-MS analysis is used to understand the nature of active principles in C. anisata and that may be helpful for further detailed studies.

\section{CONCLUSION}

GC-MS method is a direct and fast analytical approach for identification of bioactive compounds and only limited amount of plant material is required. The present study, which reveals the presence of bioactive compounds in ethanolic stem extract of $C$. anisata possess antioxidant, anti-inflammatory, antimicrobial, in sectifuge and cancer preventive that

Table 1: Chemical composition of ethanolic stem extract of $C$. anisata

\begin{tabular}{|c|c|c|c|c|c|}
\hline S.No & RT & Name of the Compound & Molecular Formula & MW & Peak area \% \\
\hline 1 & 17.18 & Pentadecanoic acid, 13-methyl ester-, methyl ester & $\mathrm{C}_{17} \mathrm{H}_{34} \mathrm{O}_{2}$ & 270.450 & 1.876 \\
\hline 2 & 17.83 & n-hexadecanoic acid & $\mathrm{C}_{16} \mathrm{H}_{32} \mathrm{O}_{2}$ & 256.424 & 78.54 \\
\hline 3 & 18.9 & 8-octadecenoic acid, methyl ester, [E]- & $\mathrm{C}_{19} \mathrm{H}_{36} \mathrm{O}_{2}$ & 296.487 & 6.638 \\
\hline 4 & 19.12 & Heptadecanoic acid, 9-methyl-, methyl ester & $\mathrm{C}_{19} \mathrm{H}_{38} \mathrm{O}_{2}$ & 298.503 & 2.985 \\
\hline 5 & 19.52 & Octadec-9-enoic acid & $\mathrm{C}_{18} \mathrm{H}_{34} \mathrm{O}_{2}$ & 282.47 & 2.67 \\
\hline 6 & 21.73 & Dipyrimadole & $\mathrm{C}_{24} \mathrm{H}_{40} \mathrm{~N}_{8} \mathrm{O}_{4}$ & 504.626 & 0.686 \\
\hline 7 & 23.32 & $\begin{array}{l}\text { (3,4-dimethyl-5-oxo-2,5-dihydr0-1H-pyrrol-2yl)- } \\
\text { (4,4-dimethyl-5-(2,3,3-trimethyl-5-methylthio-3,4- } \\
\text { dihydro-2H-pyrrol-2-yl methylene) pyrrolidin-2- } \\
\text { ylene)-thioacetic acid, 3-(tert, -butyl) ester }\end{array}$ & $\mathrm{C}_{27} \mathrm{H}_{41} \mathrm{~N}_{3} \mathrm{O}_{2} \mathrm{~S}_{2}$ & 503.763 & 2.134 \\
\hline 8 & 25.45 & $\begin{array}{l}\text { Isoxazole, 5-(3,3-dicyano-1-cyclohexylidene-2- } \\
\text { morpholino-prop-2-enyl)-3-p-methoxy phenyl- }\end{array}$ & $\mathrm{C}_{25} \mathrm{H}_{26} \mathrm{~N}_{4} \mathrm{O}_{3}$ & 430.498 & 2.340 \\
\hline 9 & 28.42 & Dipyrimadole & $\mathrm{C}_{24} \mathrm{H}_{40} \mathrm{~N}_{8} \mathrm{O}_{4}$ & 504.626 & 2.13 \\
\hline
\end{tabular}




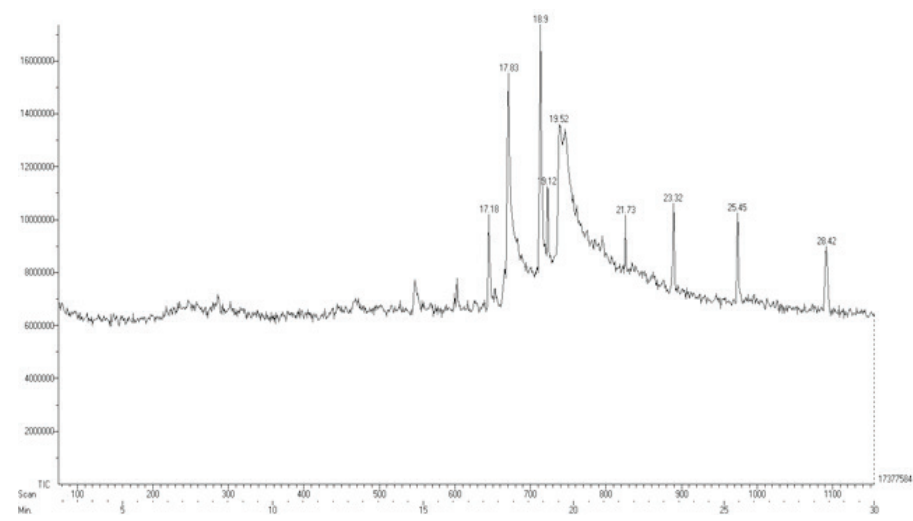

Figure 1: GC-MS chromatogram of ethanolic stem extract of C. anisata

suggests to evaluate the contribution of these bioactive compounds in pharmacology. However, further studies are needed to ascertain its bioactivity.

\section{ACKNOWLEDGEMENT}

We would like to thank Department of Biotechnology, Jamal Mohamed College, Trichy, Tamilnadu and King Fahd medical Research Centre , Jeddah, K.S.A. for their support.

\section{CONFLICT OF INTERESTS}

All authors disclose no conflict of interest

\section{ABBREVIATIONS}

NIST: National Institute of Standards and Technology; RT: Retention Time; MW: Molecular weight; GC-MS: Gas Chromatography Mass Spectrometry.

\section{REFERENCES}

1. Arbab IA, Abdul AB, Aspollah M, Abdullah R, Abdelwahab SI, Ibrahim MY and Ali LZ. A review of traditional uses, phytochemical and pharmacological aspects of selected members of Clausena genus (Rutaceae). Journal of Medicinal Plants Research. 2012;6(suppl 38):5107-18. http://dx.doi.org/10.5897/JMPR12.317.

2. Annan K, Kojo Al, Cindy A, Samuel AN and Tunkumgnen BM. Profile of heavy metals in some medicinal plants from Ghana commonly used as components of herbal formulations. Pharmacognosy. 2010;(2suppl 1):41-4. http://dx.doi. org/10.4103/0974-8490.60579; PMid:21808538 PMCid:PMC3140128.

3. Grubb PJ, Jackson RV, Barberis IM, Bee JN, Coomes DA, Dominy NJ et al. Monocot Leaves are Eaten Less than Dicot Leaves in Tropical Lowland Rain Forests: Correlations with Toughness and Leaf Presentation. Annals of Botany. 2008:101 (9):1379-89.http://dx.doi.org/10.1093/aob/mcn047; PMid:18387972 PMCid:PMC2710256.

4. Jain SK and Srivastava S. Traditional uses of some Indian plants among islanders of the Indian Ocean. Indian journal of traditional knowledge. 2005: 4(suppl 4): 345-57.

5. Ajibesin KK, Ekpoa BA, Bala DN, Essien EE and Adesanya SA. Ethnobotanical survey of Akwa Ibom State of Nigeria. Journal of Ethnopharmacology. 2008;115(3):387408.http://dx.doi.org/10.1016/j.jep.2007.10.021; PMid:18053664.

6. Schmelzer GH and Gurib-Fakim A. Medicinal plants 2. PROTA foundation, Wageningen, Netherlands. 2013:50-4.

7. Hamza OJM, Beukel CJP, Matee MIN, Moshi MJ, Mikx FHM et al. Selemani HOAntifungal activity of some Tanzanian plants used traditionally for the treatment of fungal infections. Journal of Ethnopharmacology. 2006:108(supp 1):124-32.http://dx.doi.org/10.1016/j.jep.2006.04.026; PMid:16829001.

8. Moshi MJ, Otieno DF, Mbabazi PK and Weisheit A. The Ethnomedicine of the Haya people of Bugabo ward, Kagera Region, north western Tanzania. Journal of Ethnobiology and Ethnomedicine. 2009:5(suppl 24):1-5. http://dx.doi.org/ 10.1186/1746-4269-5-24; PMid:19715617 PMCid:PMC2739164.

9. Ojewole JAO.Hypoglycaemic effect of Clausenaanisata (Willd) Hook methanolic root extract in rats. Journal of Ethnopharmacology. 2002;81(2):231-7. http:// dx.doi.org/10.1016/S0378-8741(02)00085-5.

10. Yineger $H$, Yewhalaw $D$ and Teketay D.Ethnomedicinal plant knowledge and practice of the Oromo ethnic group in southwestern Ethiopia. Journal of Ethnobiology and Ethnomedicine. 2008:4(suppl 11):1-10. http://dx.doi. org/10.1186/1746-4269-4-11; PMid:18445249 PMCid:PMC2390512.

11. Rupande $G$ and Bukaliya R. The Efficacy of Indigenous Knowledge in Scaling up HIV/AIDS Treatment-Practices and Challenges: The Case of Zimbabwe. International Journal of Advanced Research. 2013;1(suppl 10):678-90.

12. Arumugham $S$ and Elezabeth VD. GC-MS analysis of bioactive constituents of Indigoferasuffruticosa leaves. Journal of Chemical and Pharmaceutical Research. 2014;6(suppl 8):294-300.

13. Sermakkani M andThangapandian V. GC-MS analysis of Cassia italica leaf methanol extract. Aisan Journal of Pharma Clinical Research. 2012;5(suppl 2):90-4.

14. Duke, James A., and Stephen M. Beckstrom-Sternberg. "Dr. Duke's phytochemical and ethnobotanical databases." (1994). Home Page: http://phytochem. nal.usda.gov/ http://dx.doi.org/10.15482/USDA.ADC/1239279.

15. Brown DG, Wilkerson EC and Love WE. A review of traditional and novel oral anticoagulant and antiplatelet therapy for dermatologists and dermatologic surgeons. Journal of the American academy of Dermatology. 2015:72(suppl 3):524-34. http://dx.doi.org/10.1016/j.jaad.2014.10.027; PMid:25486915.

16. Palmenberg AC and Fata-Hartley CL. Dipyridamole reversibly inhibits Mengovirus RNA replication. Journal of Virology. 2005:79(suppl 17):11062-70. http://dx.doi. org/10.1128/JVI.79.17.11062-11070.2005; PMid:16103157 PMCid:PMC1193570.

17. Sekar M, Poomalai S, Gunasekaran M, Mani P and Krishnamurthy A. Bioactive compounds from marine yeast inhibits lung cancer. Journal of applied Pharmaceutical sciences. 2015:5(suppl 2):007-015. 